\title{
Improve the Competence of Citizenship through Peace Education for Victims of the Aceh Conflict
}

\author{
Dhian Mutia, Sapriya and Muhammad Halimi \\ Department of Civic Education \\ Graduate School, Universitas Pendidikan Indonesia \\ Bandung, Indonesia \\ dhianmutia14@student.upi.edu, sapriya@upi.edu
}

\begin{abstract}
Peace education is an ongoing activity or process for creating peace in society, in the sense of peace should go in and cut the chain to the efforts of teaching, such as negotiation and mediation skills and educational values of peace that includes respect for human rights and so on, so it will bring Indonesia to a better situation. The purpose of this study was to find out how the role of peace education in improving the competence of citizenship (civic competence) victims of the conflict in Aceh. This study used a qualitative approach with case study method. The subjects of this study are some commissioners on the Truth and Reconciliation Commission for Aceh, Aceh former combatants and the families / victims of the conflict in Aceh. Data collection techniques in this study using observation, interview and documentation. Technical analysis of data is done through data reduction, data presentation, and draw conclusions / verification. The results showed peace education programs undertaken by the Truth and Reconciliation Commission in Aceh showed an increase in the competence of citizenship victims of the conflict in Aceh.
\end{abstract}

Keywords—civic competence; peace education

\section{INTRODUCTION}

Indonesia is a country that was built in a very large diversity, this diversity is a blessing for the people of Indonesia in particular be a pride for its residents. However, this diversity can only be a 'boomerang' in itself because if it cannot with good management can result in a conflict that could undermine national unity. Conflicts based on differences in SARA that lead to physical and psychological violence is very common in this nation. The clash that led to the loss of life that was basedbacks differences in ethnicity, religion, race and groups have become tales of melancholy in the pre- and post-independence history of Indonesia. This was proven when Aceh experienced a prolonged conflict that lasted for more than 30 years. During this period, thousands of civilians and the two groups clashed become victims. But in the end August 15th, 2005 a peace treaty was conducted in the City of Helsinki, Finland.

Aceh is an area which is just out of the "zone of conflict", peace in Aceh is not enough merely signing Memorandum of Understanding (MoU), but more than that we need the support factors so that it can be enduring and avoid wherever possible thing that can lead society into the arena of conflict. There are four general crisis that can disrupt the peace of economy, politics, military, culture and education. Although the Aceh peace has lasted for nearly 13 years, but a number of challenges still to be faced. The results of the study of the Institute for Development of Acehnese Society (IDEAS) of the most recent publications BPS RI (bps.go.id) on Monday (7/17/2017) poverty level remains high, reaching 16.89 percent and 10.64 percent unemployment, quality health and education services are also not satisfactory. This is what still a big problem is, but for some people of Aceh are enjoying security conduciveness, seta trying to preserve and maintain the peace in Aceh. On the other hand, people who are victims of conflict, which lasted for nearly thirty years was yet to get justice rights. During this time of conflict affected communities are already in despair, all the roads have been in the travel to fight for justice for them, especially the sense of justice for their families, at least they need practical assistance in a specific manner. When the state of society filled with chaos, conflict and there is no peace, then education is seen as one of the parties involved are guilty of failing to realize the good citizens [1]

After the violence subsided conflict, peace work is directed to the purpose of long-term social changes that put more emphasis on structural reconstruction of peace in society. Peace is not merely the absence of war, but a dynamic state, conducive, participatory and long-term based on the universal values in all, practical level such as family, school, society, communities and countries. In the concept in the offer of the United Nations (UN) through UNESCO emphasized that for the realization of a culture of peace is important to not solely focus on rebuilding societies torn by conflict, but also prevent violence by spreading a culture. Education was used as an approach to reducing conflict and violence is already a discourse especially peace education. Therefore, as an antidote chaos, the role of peace education can be used as a method of implanting a place for moral values that support the creation of peace in society.

One of the most important and urgent concerns one country or one ideology but is a concern of all people in the world, is education for peace and justice. Destiny and the future of mankind depends on two concepts: peace and justice. Lasting peace is a basic capital to build to reach a prosperous country. Triggers other conflicts can be caused by ignorance or lack of understanding of a country against other countries, lack of knowledge about what other people think, clothing, and food, 
celebrate and do for fun can also drag us in a conflict. Preamble to the Constitution of UNESCO [2] states that "Since wars begin in the minds of men, it is in the mind of men the maintenance of peace must be constructed" and the development of the human mind can only be done through education. peace education is an activity or an ongoing process of creating peace in society, in the sense of peace should go in and cut the chain to the efforts of the teaching of skills such as negotiation and mediation as well as the educational values of peace that includes respect for human rights and so on, so it will bring Indonesia to a better situation.

Generally, the material in peace education is to inculcate attitudes to become good citizens. This is consistent with the objective of citizenship education is to form good citizens and smart (to be smart and good citizen) [3]. A citizen is first necessary to have knowledge of good citizenship, then a citizen is expected to have the skills intellectual and participatory way in the life of nation and state, so with the knowledge and skills that they have to respond to a question wisely without violence, this condition requires alternative solutions opted in all components of society through a social activity.

\section{THEORETICAL}

Education can be used as one to reduce uncivilized, in this case peace education, which is part of the education may reduce it, in short, peace education as "a system or process that allows participants to empower themselves with knowledge, skills, attitudes, values and beliefs building a culture of peace, non-violence and the ability to survive" [4]. it is in line with the concept of a culture of peace that aims namely dismantle the culture of war, living with justice and compassion, to promote the rights and responsibilities of men, to build a culture of respect, reconciliation and solidarity; living in harmony with the environment and inner peace. For others, talking about foster peace education skills. The ultimate goal is to learn how to generate non-violent tendencies and conflict resolution. This can be done in schools, violence prevention programs, peer mediation and conflict resolution program [5]. There is another opinion too, that peace education can be a mechanism to promote peace-making and reconciliation in the context of harsh conflict [6]. This can be done by various methods that can be useful in promoting peace education, such as the use of mass media, communal and community empowerment interventions, and efforts by local and international NGOs. Peace education has many faces depending on the needs and goals of the people involved in it, when people are involved in a difficult conflict, peace education goal is to promote and facilitate the creation of peace and reconciliation [7]. UNICEF stated that peace education is needed in every community, not only in countries that are at war or emergency. Effective peace education requires a long-term process, not just a short-term intervention. Although often based schools and learning in an ideal peaceful environment should involve the community in the vicinity.

Peace education aims to develop citizens with the ability to cope with difficult and uncertain situations, and the ability to resolve conflict through non-violent means [8], but basically only teach peace education about how violence and conflicts can occur and inform how to keep the peace, make peace, if conflict and violence has occurred and build peace. However, peace education, teach respect for differences, instilling the values of tolerance, mutual respect understanding openness to diversity of ethnic, cultural and religious.

Skills citizenship (civic competence) is a blend of civic knowledge with civic skills [9]. Civic competence is the ability to be owned by a person as a citizen. The three main components of this civic competence are being developed in the aim of civics for someone to be a good citizen and intelligent.

Civic knowledge related to the content or what in the know citizens. This knowledge is fundamental structures and political systems, governments and social systems are ideal as documented in the life of the nation and the universal values of democratic societies and ways of cooperation to realize common progress and peaceful coexistence in society. Furthermore, Ivanov (1998) provides an overview of the knowledge of citizenship as follows: "Civic knowledge Consist of fundamental ideas and information that learners must know and use to become effective and responsible citizens of a democracy" [10]. Furthermore, Citizenship Skills or (civic skills) is a skill developed from knowledge of citizenship, so that the knowledge obtained into a meaningful, since it can be utilized in dealing with the problems of the nation and state. If citizens practice their rights and fulfill its obligations as a sovereign member of society, citizens do not only need to master the basic knowledge. Civic skills include Intellectual skills (intellectual skills) and participation skills (skills of participation). Intellectual skills are important for the formation of citizens who are knowledgeable, effective and responsible among other critical thinking skills. Includes critical thinking skills to identify, describe / describe, explain, analyze, evaluate, determine and hold opinions regarding public issues [11]. The third component of civic competence, namely the character of citizenship (civic disposition) implying in public or private character of citizens which are important for the maintenance and development of constitutional democracy. Bronson (1998) who argued that the nature of citizenship is the third important component of civic competence as a goal Civics [12]. The nationality character refers to the personal character traits and the public are important for the maintenance and repair of constitutional democracy. The character of citizenship is the result obtained through experience and learning for schools, communities and families. The character of citizenship refers to the character of the two properties, namely the private and public character which are both important character trait to be owned by a citizen. Personal character traits among other things: the moral responsibility, self-discipline, and respect for the value and dignity of every individual.

\section{METHODS}

This study used a qualitative approach that is considered relevant to the subject of this study. This approach is believed to provide a description is broad and deep and contains an explanation of the process or activity that happens in his everyday life. Moleong (2010) explains that a qualitative approach is research that aims to understand the phenomenon of what is experienced by the subject of the study such as behavior, perception, motivation, act holistically and in a 
descriptive way in the form of words and language in a specific context natural [13]. The method used in this research is a case study or research cases that is part of a qualitative research. Nazir (2005) explains that case study is the research subjects of the study can be individuals, groups, institutions and communities, so as to provide a detailed overview of the background, characteristics and characters typical of the above will used as a matter of a general nature [14]. This research was focused on the phenomenon have on the implementation of the peace education program in Banda Aceh in depth. This research was conducted in the Office of the Aceh Truth and Reconciliation Commission. The informants consist of several commissioners in the Aceh Truth and Reconciliation Commission, the Manager of the School of Human Rights Flower Aceh, a former combatant, as well as families / victims of the conflict. Data collection techniques in this study using observation, interview and documentation. Then the results of data collection were analyzed through data reduction, data presentation, and draw conclusions / verifications.

\section{RESULTS AND DISCUSSION}

After the Helsinki peace no longer Aceh conflict areas, but conditions still fragile peace so that conflicts can be resurfaced later. Aceh Peace absolutely must be maintained in order for goals to advance and prosper society and conflict victims in need of attention from the government. Continuous conflicts experienced nearly 30 years it leaves major problems faced to put the experience of victims and keep the peace. Conflict is the reality of human life that is natural. Conflicts born as human beings have a tendency, desires and interests are different from each other. Based on the results of interviews with victims of the Aceh conflict causes of conflict in the past caused by the difference in views between the people of Aceh and the central government that led to the policy decision that is considered unfair, discriminatory and policies that lead to violence. When analyzed further, the various policies that have spawned threats and violence actually will not happen if the conflict can be managed properly. Moreover, in the context of violence in Aceh decades ago, as well as powerful embedded history and magnitude of the effects of violence and the problems of social injustice and economic inequality faced by apparently it caused the destruction of the whole order of life of the people of Aceh. The conflict has caused tens of thousands of deaths, destruction of property and economic life, social cuts and peeled order of religious life, customs and culture. Various efforts have been undertaken mainly by civil society, rather the human rights activists to the sustainability of peace in society. Thus, through peace education programs undertaken by the Aceh Truth and Reconciliation Commission consisting of individuals later formed a group that has the purpose of strengthening peace and uncover the truth about human rights violations that occurred in the past.

Peace education imposed either in conflict or non-conflict of aims for education development, disarmament education, conflict resolution, environmental education, and human rights education. Reconciliation in areas of conflict that are not controlled beyond the formal conflict resolution agenda for change motivation, goals, beliefs, attitudes, and emotions that occur among the majority of people - on the conflict, the nature of the relationship between the parties, and the nature of his own party [7]. Reconciliation is composed of mutual recognition and acceptance, investments in the development of peaceful relations, mutual trust and a positive attitude, and encourage sensitivity and consideration of the needs and interests of others. Peace education programs undertaken by the Truth and Reconciliation Commission in Aceh is instilling the values of peace, facilitate the knowledge and understanding of the victims of the conflict in respond an issue as well as peace education is not directly dealing with conflict (of interest, historical value, cost, or imagery competitors) on the contrary, is concerned with peacemaking avoid direct collision with the culture of conflict, especially the ethic conflict or with a series of themes and skills that did not refer to the ongoing conflict. This type of peace education can focus on the choice of themes such as identity, violence, empathy, human rights and conflict resolution skills. This is evidenced from several seminars / dissemination of peace education in Berik's by the Truth and Reconciliation Commission in Aceh for victims of conflict and human rights form the school for students who are the baton between the government and the community to sustain the peace.

From the discussion above, the peace education program showed an increase in the competence of citizenship (civic competence) victims of the conflict in Aceh. This is evident from the changes being experienced by them, such as startconfidence resulting from the knowledge that in the can (civic knowledge), able to control themselves (civic disposition), control of emotions to the surrounding environment and begin to engage in social activities at home (civic skills). Civic competence is the combination of civic knowledge with the skills of citizenship or civic skills which is the goal of peace education through knowledge, expertise and skills of a citizen, the continuation of the peace is maintained and to prevent any possibility of re-emergence of conflict to the surface.

\section{CONCLUSION}

The conflict has existed since human beings in the world. Conflict is the reality of human life that are natural, conflict is born because humans have a tendency, desires and interests are different from each other. The diversity of views and interests have led to humans in a state of conflict. The conflict has caused tens of thousands of deaths, destruction of property and economic life, social cuts and peeled order of religious life, customs and culture peace.

Aceh absolutely must be maintained in order for goals to advance and prosper society and conflict victims in need of attention from the government. Prominent and efficient method to promote reconciliation is peace education. Through peace education programs undertaken by the Aceh Truth and Reconciliation Commission consisting of individuals later formed a group that has the purpose of strengthening peace and uncover the truth about human rights violations that occurred in the past.

\section{REFERENCES}

[1] D. Darmansjah, Soft Power To Aceh; Konflk resolution and PoliticalDecentralization. Jakarta: Gramedia Pustaka Utama, 2013. 
[2] S. Kartadinata, Rusdi Yadi and Afandi Idrus, Peace Education. Bandung: PT Rosdakarya Offset Bandung, 2015.

[3] A.A. Wahab and S. Sapriya, Theory and Platform for CivicEducation.Bandung: Alfabeta, 2011.

[4] T.M. Turay and L.M. English, Toward a Global Culture of Peace (902) pp 286-301, 2008.

[5] S. Salomon, G. Gavriel and B. Nevo, Peace Education: The Concept, Principles, and Practice Around The World. London: Erlbaum Associates Lawrance, 2002.

[6] M.M. Grodofsky, Community-based human rights advocacy and peace educationpractice, 2012.

[7] D. Bar-tal, Peace Education in Societies Involved in intractable Conflicts: Direct and IndirectModels, 79 (2) pp 557-575, 2009.
[8] J. Bennet, "An Ethical Dilemma: Religious Foundamentalism and Peace Education”, Ethical Perspective.V. 18. No. 2. pp 197-228, 2011.

[9] U.S. Winataputra, Citizenship Education in the Perspective of Education for Life Feeding the Nation (Ideas, Instrument and Praxis). Bandung: Widya Script Press, 2015.

[10] I.P. Ivanov, Civic Education and Intercultural Education, 1998.

[11] W. Winarno, Citizenship Education Learning content, and learningstrategies. Jakarta: Earth Literacy, 2013.

[12] M.S. Bronson, The Role of Civiv Education. 1999, Excerpts of speech at http://www.civiced.org/papers/articles_role.html

[13] M. Moleong, Qualitative Research Methodology. Bandung: PT Young Rosdakarya, 2010.

[14] M. Nazir, Methods. Jakarta: Ghalia Indonesia, 2005. 